\title{
Air pollutants and their possible health effects at different locations in Dhaka
} city

Mohammad Zahangeer Alam ${ }^{1}$, Eva Armin ${ }^{1}$, Md. Manjurul Haque ${ }^{1}$, Joan Halsey ${ }^{2}$, and Md. Abdul Qayum $^{3}$

${ }^{1}$ Department of Environmental Science, Bangabandhu Sheikh Mujibur Rahman Agricultural University (BSMRAU), Gazipur-1706, Bangladesh

${ }^{2}$ Washington State University, Pullman WA99164-6420, USA

${ }^{3}$ Agricultural Statistics Division, Bangladesh Rice Research Institute (BRRI), Gazipur-1701, Bangladesh

*Corresponding author: Mohammad Zahangeer Alam, Department of Environmental Science, Bangabandhu Sheikh Mujibur Rahman Agricultural University (BSMRAU), Gazipur-1706, Bangladesh, E-mail: mohammad.alam@wsu.edu

Received: March 13, 2018; Accepted: April 03, 2018; Published: April 09, 2018

\begin{abstract}
Air pollution is a major environmental risk. For many decades, air pollutants have increased dramatically in the city of Dhaka. Study of air pollutants in Dhaka, as well as other urban areas, is significantly important for the sustainable environment. The present research is focused on air pollutants and their possible health effects in the areas of Dhaka city. Different pollutants such as, volatile organic compounds (VOC, s), carbon monoxide (CO), relative humidity (RH), nitrogen oxide (NOx), hydrogen sulfide $\left(\mathrm{H}_{2} \mathrm{~S}\right)$, carbon dioxide $\left(\mathrm{CO}_{2}\right)$, oxygen $\left(\mathrm{O}_{2}\right)$,sulfur dioxide $\left(\mathrm{SO}_{2}\right)$, particulate matter $(\mathrm{PM10})$, particulate matter $(\mathrm{PM} 2.5)$, suspended particulate matter (SPM), and lead $(\mathrm{Pb})$ were found to be at hazardous levels in this study area. The VOC was found to have a statistically positive correlation with $\mathrm{CO}, \mathrm{RH}, \mathrm{NOx}, \mathrm{H}_{2} \mathrm{~S}, \mathrm{CO}_{2}, \mathrm{PM10}, \mathrm{PM} 2.5, \mathrm{SPM}$, and $\mathrm{Pb}(\mathrm{p}<0.01 ; 0.01<\mathrm{p} \leq 0.05 ; 0.05<\mathrm{p} \leq$ 0.1). Similarly, a positive correlation was found between each of $\mathrm{CO}_{2}, \mathrm{CO}, \mathrm{SO}_{2}, \mathrm{NOx}_{2} \mathrm{H}_{2} \mathrm{~S}, \mathrm{SPM}, \mathrm{PM10}$, PM2.5, and Pb. These air pollutants have significantly increased from June 2016 to July 2017 at different locations in Dhaka. According to public perception and health physicians, air pollutants contribute to health concerns such as, eye irritation, headaches, damage to kidneys and central nervous system, skin cancer, cardio vascular diseases, nausea, asthma, and anemia. Regular monitoring of air quality parameters can be effective to protect inhabitants from various illnesses as well as significant help in providing a guideline for the development of a sustainable environment in the city dwellers of Dhaka.
\end{abstract}

Keywords: Pollutants; Dhaka; Health; Volatile; Air

\section{Introduction}

Pollutants are released into the air from their different sources [1]. Acts have been generated throughout the world in an attempt to regulate these pollutants and keep them from reaching levels that are hazardous to humans [2]. For instance, the European Commission has developed regulations for monitoring and reduction of air pollutant concentrations in the atmosphere [3]. Several recognized methods are already being used to monitor the levels of $\mathrm{SO}_{2}, \mathrm{NOx}$, particulate matter

Citation: Alam ZM, Armin E, Haque MM, et al. Air pollutants and their possible health effects at different locations in Dhaka city. J Curr Chem Pharm Sc. 2018; 8(1):111.

(C) 2018 Trade Science Inc. 
www.tsijournals.com | April-2018

(PM), lead, and ozone $\left(\mathrm{O}_{3}\right)$ [4]. There are usually about 200 air pollutants present in an urban environment. Most of these pollutants are quite hazardous and make it difficult to maintain a sustainable and healthy environment [3]. The concentrations of each pollutant in the atmosphere depend on the emission rates of their sources [3]. Levels of concentration of these pollutants in the atmosphere are also variable with time and location throughout the world [5].

The atmospheric chemistry is highly dependent on the living organisms in the biosphere [6]. The composition of the earth's atmosphere has been changed over time by human activities [7]. Some of these fluctuations are harmful to human health, crops and ecosystems [6,7]. While humans are the integral part of an ecosystem, the urban ecosystem is unpleasantly affected by increased several air pollutants such as particulate matter (PM) and hazardous air pollutants (HAPs) [8,9]. This air pollution can be observed ashaze, smog and acid rain particularly in urban and industrialized cities [10]. The real detrimental effects can be seen in the health of people and the environment, for example, PM10has increased morbidity and mortality rates due to cardiovascular and respiratory illness [10,11]. Exposure to carbon monoxide can cause fatigue, headaches, dizziness, loss of consciousness and even death [12]. Nitrogen oxides and sulfur dioxide also impairs the immune system, increases asthma and chronic respiratory diseases, reduces lung function and increases cardiovascular disease [9,12].

Air pollutants are classified based on the different human activities [13]. These pollutants can be categorized as, motor traffic, industry, power plants and domestic fuel $[11,13,14]$. Road traffic is identified as a major contributor to the air pollution due to the poor maintenance of vehicles, older cars, and two-stroke engine vehicles $[8,13,15]$. Dhaka as well as the city of Lagosisa commercial hub, where many industries are located. These industries contribute significantly to air pollution because they emit smokes and gases of various magnitudes from their diesel powered engines. The unplanned growth of several mega cities, including Dhaka, causes housing and industrial locations to arise indiscriminately and haphazardly resulting in additional environmental hazards [16].

Trace gases in the atmosphere are found at low concentrations; even at this concentration, they can exert considerable influence on a range of environmental processes and health problems [17]. Understanding the interactions between gases is crucial to know their atmospheric concentrations, lifetimes and the environmental impacts [17]. Ozone $\left(\mathrm{O}_{3}\right)$, nitrogen oxides $(\mathrm{NOx})$, carbon monoxide $(\mathrm{CO})$, and sulfur dioxide $\left(\mathrm{SO}_{2}\right)$ react with many other compounds such as volatile organic compounds (VOCs) leading to changes in atmospheric composition [18].

For well over a decade, attempts have been made to introduce an Ambient Quality Index (AQI) based on standard guidelines proposed by international organizations, such as the United States Environment Protection Agency (US-EPA), the European Union (EC) and the World Health Organization (WHO). For instance, Khanna [19] developed an AQI based on the welfare losses associated with damage from pollution exposure, while Murena [20] introduced a procedure for evaluating the air quality at each monitoring site as well as the overall urban domain. Kyrkilis et al. [21] proposed an aggregated air quality index in relation to potential health effects, while Cairncross et al. [22] suggested a novel Air Pollution Index (API) system based on the relative risk and increased daily mortality associated with short-term exposure to common air pollutants. Kassomenos et al. [23] compared a number of indices for assessing air quality in a medium-size city, as well as a set of bio meteorological indices taking into account the adverse health effects of air pollution, while Llop et al. [24] proposed functional groups of epiphytic lichens as indicators of air quality in South Portugal [25]. 
www.tsijournals.com | April-2018

Air pollution is also influenced by road traffic [26]. For instance, South East Franceas well as Dhaka city is one of the regions most influenced by atmospheric pollution [25]. The population of the city of Dhaka has been increasing dramatically [27]. This population has been facing obnoxious levels of hazardous air particles; As a result air and water are becoming threatened as well. Currently Dhaka ranks high amongst the world's major cities in terms of poor urban air quality [26]. Substantially reducing air pollution could save up to 3,500 lives and avoid up to 230 million cases of respiratory disease annually in Bangladesh. In economic terms, this is equivalent to around US\$ 500 million in savings due to reduced health care costs and increased productivity per annum [28]. We studied air quality parameters at different locations in the mega city of Dhaka and their impacts on health for a sustainable livelihood for the residents. We identified Dhaka as highly polluted due to the large number of vehicles and one of the highest population densities in the world. It is the hypothesis that air pollutants can be reduced through the monitoring of air quality parameters regularly which will be helpful for the reduction of the impact on health.

\section{Materials and methods}

\section{Description of study areas}

Dhaka is the most densely populated city in Bangladesh, with a density of 23,234 people per square kilometer. Currently, it is recognized as a mega city in comparing its population to other cities throughout the world. This city itself has a population estimated at about 8.5 million [29]. Several of the air quality parameters were examined in 7 locations of Dhaka. These locations are Brick Fields in Savar, Dhaka cantonment, West rasulpur, Birulia at Savar, North DEPZ of Savar, South DEPZ of Savar, East DEPZ of Savar and West DEPZ of Savar. The Geographical Positioning System of Dhaka city is altitudes $23^{\circ} 42^{\prime} 37.44^{\prime \prime} \mathrm{N}$ and longitude $90^{\circ} 24^{\prime} 26.78^{\prime \prime} \mathrm{E}$. The study area on a Bangladesh map and locations for the detection of air quality parameters are highlighted in FIG. 1 and 2, respectively.

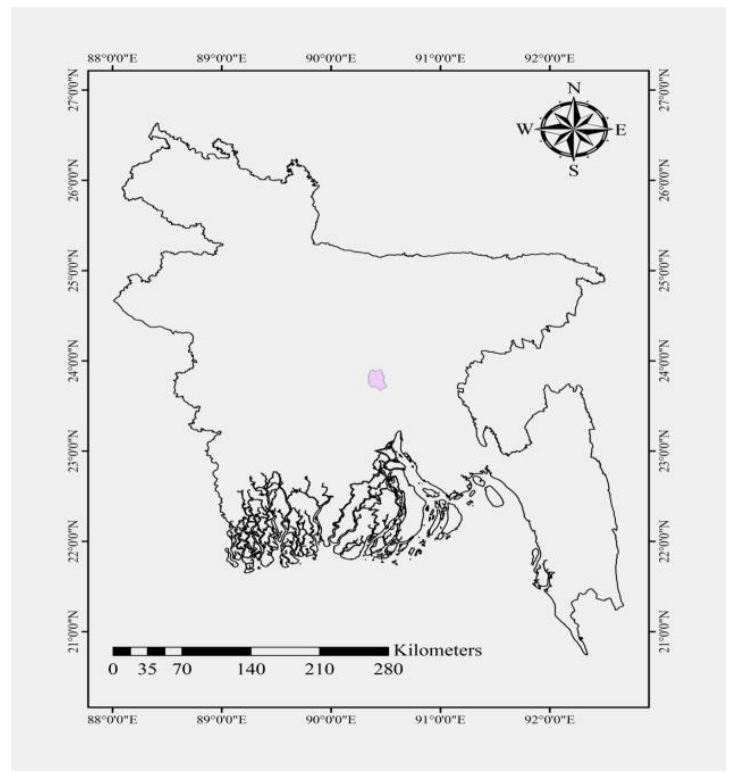

FIG. 1 


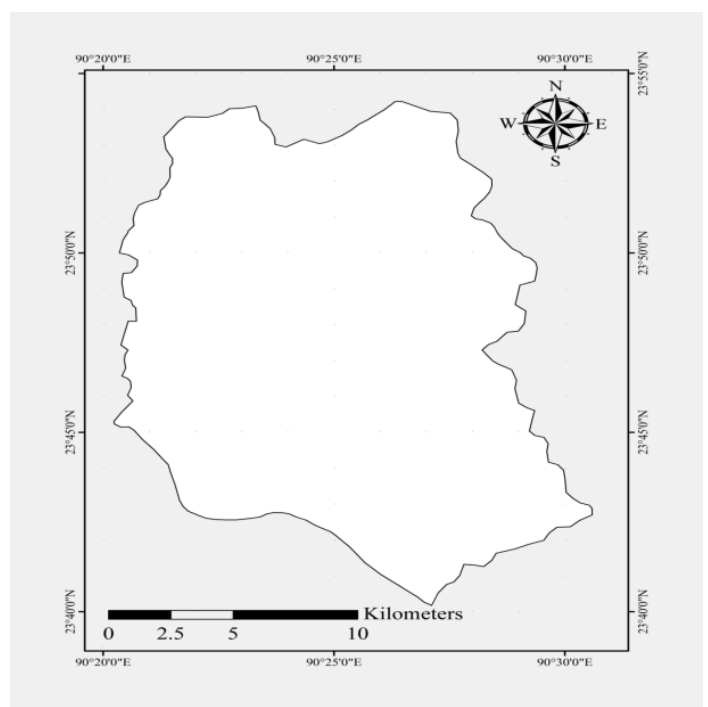

FIG. 2. Study location of air quality parameters

\section{Inception meeting}

An inception meeting was arranged at the office of the Bangladesh Council of Scientific and Industrial Research (BCSIR) in Dhaka that lasted for 3 days. This meeting was conducted with government officials, residents, visitors, health physicians, scientists, and many other people who have been living in this city for a long time. This meeting was conducted to discuss air pollutants and their possible health effects in Dhaka. During this meeting, participants contributed their unique perspectives regarding air quality in Dhaka and their own health effects. Through this meeting, major areas of pollution were identified among the different locations in Dhaka.

\section{Public perception}

Based on the inception meeting, we have collected data regarding the effects of pollutants on human health in Dhaka. This information was gathered from different locations in the city of Dhaka. Collected data were noted from the perceptions of the general public including health physicians. Each group consisted of 18-20 people. The people who were interviewed were 40-50 years old and their level of education was from secondary to graduate level. Everyone was in agreement that the health hazards have been increasing tremendously over more than a decade due to the deterioration of air quality in the urban environment.

\section{Toxic gases}

Volatile Organic Compounds (VOCs), Carbon dioxide (CO2), Carbon mono oxide (CO), oxygen $\left(\mathrm{O}_{2}\right)$, percentages of relative humidity, sulfur dioxide $\left(\mathrm{SO}_{2}\right)$, nitrogen oxide $(\mathrm{NOx})$, and hydrogen sulfide $\left(\mathrm{H}_{2} \mathrm{~S}\right)$ were measured using a real time monitoring system of a toxic gas measuring instrument with PID, NDIR and electrochemical sensors (Direct Sense Advanced Environmental Instrumentation, Grey Wolf Sensing Solutions, USA).

\section{Air Particles}

PM2.5, PM10, and SPM were measured through real time monitoring with Casella Micro Dust Pro CEL-712 according to ISO 12103-1 and also the gravimetric method followed by filter sampling. Air dust particles were collected by a 
www.tsijournals.com | April-2018

low volume air sampler on previously weighted PM 2.5, PM 10 and repairable filter by microbalance with a minimum resolution of $0.001 \mathrm{mg}$.

\section{Air sampling for monitoring of Lead (Pb)}

The $\mathrm{Pb}$ in the air sample was determined according to the [30] A dust sampling starter kit including filter paper, sampling head, flow meter, air sampling pump and other accessories were used for the analysis of Pb in air samples. First air samples were collected in Mixed Cellulose Esters (MCE) Filters (Diameter: 25 mm, Pore Size: $0.8 \mu \mathrm{m}$ ) using a Casella APEX air sampling pump. MCE membrane filters are readily soluble and one of the most widely used filters for atomic absorption analysis. Sampling was done at an accurately known flow rate $3.5 \mathrm{~L} / \mathrm{Min}$ up to $8 \mathrm{~h}$ for a total sample size of 1 to $1500 \mathrm{~L}$

\section{Laboratory analysis}

The filter paper was kept in a filter holder and transferred into a clean beaker. The $3 \mathrm{~mL}$ concentrated $\mathrm{HNO}_{3}$ and 1 $\mathrm{mL} 30 \% \mathrm{H}_{2} \mathrm{O}_{2}$ was added and covered with a watch glass. The sample was heated on hotplate at $140^{\circ} \mathrm{C}$ until volume was reduced to about $0.5 \mathrm{ml}$. The beaker was cooled down and the watch glass and walls of the beaker were rinsed with $5 \%$ HNO3. The solution was quantitatively transferred to a $10 \mathrm{~mL}$ volumetric flask and diluted to volume with ultra-pure water. Then the sample was taken into a Graphite Furnace Atomic Absorption Spectrophotometer (Shimadzu -7000A) for the analysis of lead $(\mathrm{Pb})$.

\section{Statistical analysis}

Significant levels of correlation between air pollutants were analyzed for the validation of data using R Software, version 3.2.2 (R Foundation for Statistical Computing, Vienna, Austria). Coefficient trends were analyzed for the increasing of air pollutants in Dhaka city using R software version 3.2.2 (R Foundation for Statistical Computing, Vienna, Austria).

\section{Results}

\section{Volatile Organic Carbon (VOC)}

The VOC was found to have a statistically positive correlation with carbon monoxide (CO), relative humidity(RH), nitrogen Oxide (NOx), hydrogen sulfide $\left(\mathrm{H}_{2} \mathrm{~S}\right)$, particulate matter $(\mathrm{PM} 10)$, particulate matter $(\mathrm{PM} 2.5)$ and lead $(\mathrm{Pb})(\mathrm{p}<0.01$; $0.01<\mathrm{p} \leq 0.05 ; 0.05<\mathrm{p} \leq 0.1)$ at different locations in Dhaka city during August, 2016 TABLE 1. Similarly, this VOC was found positively correlated with carbon dioxide $\left(\mathrm{CO}_{2}\right), \mathrm{NOx}, \mathrm{H}_{2} \mathrm{~S}$, suspended particulate matter (SPM), PM10, PM 2.5, and $\mathrm{Pb}(\mathrm{p}<0.01 ; 0.01<\mathrm{p} \leq 0.05 ; 0.05<\mathrm{p} \leq 0.1)$ during December 2016 TABLE 2 . In April, 2017 VOC was found significantly correlated with CO2, H2S, PM2.5, and Pb (TABLE 3). Since 2016, VOC was significantly increased at Savar Brick Fields, Dhaka cantonment, West rasulpur, Birulia, North DEPZ, South DEPZ, East DEPZ, and West DEPZ areas (p<0.01; $0.01<\mathrm{p} \leq 0.05)$ TABLE 4. According to the public perception, VOC is highly responsible for the development of different health hazards such as eye irritation, headaches, coordination loss, damage to kidneys, liver and the central nervous system (neo-natal), skin cancer (human and animal), and skin allergies. These opinions were also validated through the discussion with a health physician TABLES 5 and 6. 
www.tsijournals.com | April-2018

\section{Carbon dioxide $\left(\mathrm{CO}_{2}\right)$}

Carbon dioxide $\left(\mathrm{CO}_{2}\right)$ was significantly correlated with relative humidity at different locations in Dhaka city during August, 2016 TABLE 1. Positive correlations were found between $\mathrm{CO}_{2}$ and $\mathrm{CO}, \mathrm{SO}_{2}, \mathrm{NOx}, \mathrm{H} 2 \mathrm{~S}, \mathrm{SPM}, \mathrm{PM} 10$, PM2.5, and $\mathrm{Pb}$ during December, $2016(\mathrm{p}<0.01 ; 0.01<\mathrm{p} \leq 0.05 ; 0.05<\mathrm{p} \leq 0.1)$ (TABLE 2 ). This toxic gas was also significantly correlated with RH, SPM, PM2.5, and Pb in April, $2017(0.01<\mathrm{p} \leq 0.05 ; 0.05<\mathrm{p} \leq 0.1)\left(\right.$ TABLE 3). $\mathrm{CO}_{2}$ was increased significantly at Savar Brick Fields, Dhaka cantonment, West rasulpur, and West DEPZ areas from 2016 to $2017(0.01<\mathrm{p} \leq$ $0.05 ; 0.05<\mathrm{p} \leq 0.1$ ) (TABLE 4). According to the public perception, increased $\mathrm{CO}_{2}$ is accountable for the increase of several health problems such as cardio vascular diseases, impaired blood circulation, equilibrium concentration of oxygen in blood reducing hemoglobin, and damage to the nervous system. These results show an increase in the number of people experiencing dizziness and concentration problems within these communities TABLES 5 and 6.

\section{Carbon monoxide (CO)}

Carbon monoxide (CO) was found to have a positive relationship with $\mathrm{SO}_{2}, \mathrm{NOx}, \mathrm{H}_{2} \mathrm{~S}$, SPM, PM10, and PM 2.5 during August, 2016 ( $\mathrm{p}<0.01 ; 0.01<\mathrm{p} \leq 0.05 ; 0.05<\mathrm{p} \leq 0.1)$ (TABLE 1). This gas was also significantly correlated with $\mathrm{SO}_{2}$, NOx, $\mathrm{H}_{2} \mathrm{~S}$, SPM, PM10, PM2.5, and Pb during December, 2016 (p<0.01) (TABLE 2). In April 2017, CO was positively correlated with $\mathrm{SO}_{2}, \mathrm{NOx}, \mathrm{H}_{2} \mathrm{~S}$, and PM2.5 ( $\left.\mathrm{p}<0.01 ; 0.01<\mathrm{p} \leq 0.05 ; 0.05<\mathrm{p} \leq 0.1\right)$ (TABLE 3). These air pollutants were significantly increased in different locations in Dhaka city such as, Savar Brick Fields, Dhaka cantonment, Birulia, North DEPZ, South DEPZ, East DEPZ, and West DEPZ areas from July 2016 to June 2017. Oxygen carrying capacity is reduced significantly due to the increase of this toxic gas in the atmosphere which is similar to the health physician's perception (TABLE 5).

\section{Oxygen $\left(\mathrm{O}_{2}\right)$}

Significant relationships were found between $\mathrm{O}_{2}, \mathrm{SO}_{2}$ and NOx in August $2016(\mathrm{p}<0.01)$ (TABLE 1). This

relationship was not correlated, however, in December 2016 and April 2017 (TABLES 2 and 3). This $\mathrm{O}_{2}$ was found increased in West rasulpur, Birulia, and South DEPZ from 2016 to 2017 ( $p<0.01 ; 0.01<\mathrm{p} \leq 0.05 ; 0.05<\mathrm{p} \leq 0.1)$ (TABLE 4). High flow of this gas causes death (TABLES 5 and 6).

\section{Relative Humidity (RH)}

The RH was slightly correlated with, NOx, $\mathrm{H}_{2} \mathrm{~S}$, and PM10 gases during August $2016(0.05<\mathrm{p} \leq 0.1)$ (TABLE 1 ). This parameter was also correlated with $\mathrm{H}_{2} \mathrm{~S}$, SPM, and PM2.5 during December, 2016 ( $\left.\mathrm{p}<0.01 ; 0.01<\mathrm{p} \leq 0.05\right)$ (TABLE 2). In April 2017, it was positively correlated with PM2.5 gases $(0.01<\mathrm{p} \leq 0.05)$ (TABLE 3$)$. The RH was significantly increased in South DEPZ, East DEPZ, and West DEPZ areas from 2016-2017 ( $<<0.01 ; 0.05<\mathrm{p} \leq 0.1)$ (TABLE 4). High relative humidity causes asthma, allergies, low blood pressure, while low relative humidity can dry out and inflame the mucus membrane lining the respiratory tract, increase the risk of flu, and cause irritated sinuses according to the opinion of the public and health physicians (TABLES 5 and 6).

\section{Sulfur Dioxide $\left(\mathrm{SO}_{2}\right)$}


www.tsijournals.com | April-2018

This gas was positively correlated with NOx, $\mathrm{H}_{2} \mathrm{~S}$, SPM, PM10, and PM2.5 during August 2016. This relationship was also found to be significantly correlated in December 2017 ( $p<0.01 ; 0.01<p \leq 0.05 ; 0.05<p \leq 0.1)($ TABLES 1 and 2$)$. The $\mathrm{SO}_{2}$ was found to have a highly significant relationship with $\mathrm{H}_{2} \mathrm{~S}$ and PM2.5 in April 2017 (p<0.01) (TABLE 3). This toxic gas also significantly increased from 2016 to 2017 ( $\mathrm{p}<0.01 ; 0.01<\mathrm{p} \leq 0.05 ; 0.05<\mathrm{p} \leq 0.1)$ (TABLE 4).

\section{Nitrogen Oxide (NOx)}

Nitrogen Oxide (NOx) was positively correlated with $\mathrm{H}_{2} \mathrm{~S}$, PM10, PM2.5, and Pb during August, 2016 (p<0.01; $0.01<\mathrm{p} \leq 0.05)($ TABLE 1$)$. This gas was also significantly correlated with $\mathrm{H}_{2} \mathrm{~S}, \mathrm{SPM}, \mathrm{PM} 10, \mathrm{PM} 2.5$, and Pb in December 2016 ( $<<0.01 ; 0.05<\mathrm{p} \leq 0.1$ ) (TABLE 2). Similarly, NOx was found significantly correlated with $\mathrm{H}_{2} \mathrm{~S}$, and PM2.5 in April $2017(0.01<\mathrm{p} \leq 0.05)$ (TABLE 3). This toxic gas also significantly increased in all study locations of Dhaka from 2016 to $2017(0.01<\mathrm{p} \leq 0.05)$ (TABLE 4). According to the health physician, a lung disorder could be developed due to high increases of this gas in the atmosphere which is similar to the public perception (TABLES 5 and 6).

\section{Hydrogen Sulfide $\left(\mathrm{H}_{2} \mathrm{~S}\right)$}

Hydrogen Sulfide $\left(\mathrm{H}_{2} \mathrm{~S}\right)$ was found positively correlated with PM10, PM2.5, and Pb in August 2016 (p<0.01; $0.01<\mathrm{p} \leq 0.05)($ TABLE 1). This gas was also found in positive relationship with SPM, PM10, PM2.5, and Pb during December 2016 ( $<<0.01 ; 0.01<\mathrm{p} \leq 0.05)$ (TABLE 2). Only PM2.5 was found to have a significant relationship with $\mathrm{H}_{2} \mathrm{~S}$ in April 2017 (p<0.01) (TABLE 3). This gas has been significantly increased in Savar Brick Fields, West rasulpur, Birulia, North DEPZ, and West DEPZ areas of Dhaka from 2016-2017(p<0.01;0.01<p $\leq 0.05 ; 0.05<p \leq 0.1)(T A B L E 4)$. This gas is responsible for the development of a bad odor, as well as nausea, throat irritation, and bacterial infection among the people in these communities (TABLES 5 and 6).

\section{Particulate Matter and lead (Pb)}

Suspended Particulate Matter (SPM) was positively correlated with PM2.5; PM10 was found to have a positive correlation with $\mathrm{PM} 2.5$ and $\mathrm{Pb}(\mathrm{p}<0.01 ; 0.01<\mathrm{p} \leq 0.05 ; 0.05<\mathrm{p} \leq 0.1)$ (TABLE 1). Similarly, SPM was also found significantly correlated with PM10, PM2.5 and Pb. Also, PM10was significantly correlated with PM2.5 and Pb (p<0.01; $0.01<\mathrm{p} \leq 0.05)($ TABLE 2). Particulate Matter and Pb both were significantly increased from 2016 to 2017 at different locations in Dhaka (TABLE 4). Bronchitis, chronic cough, respiratory disease, asthma, anemia, and skin cancer is increaseddue to high increases of $\mathrm{PM}$ and $\mathrm{Pb}$ in the atmosphere according to public health and physicians (TABLES 5 and 6 ).

\section{Discussion}

Air pollution is a major environmental risk to health throughout the world. Deferent air pollutants such as, VOC, $\mathrm{CO}_{2}, \mathrm{CO}, \mathrm{O}_{2}, \mathrm{SO}_{2}, \mathrm{NOx}, \mathrm{H}_{2} \mathrm{~S}, \mathrm{SPM}, \mathrm{PM} 10, \mathrm{PM} 2.5$, and Pb are significantly correlated between each other. Some of these are positively correlated with each other in the atmosphere TABLES 1-3. Most of these air quality parameters have been significantly increased at different locations in Dhaka (TABLE 4). Similarly, air pollutants have been escalated in developed 
www.tsijournals.com | April-2018

and developing countries due to the increasing population density and unplanned urbanization for many years [31]. The World Health Organization (WHO) has estimated that in developing countries, increasing air pollutants has resulted in more than 2 million deaths per annum along with various respiratory illnesses [32]. It is reported that over 70-80\% of air pollution in mega cities in developing nations is attributed to vehicular emissions caused by a large number of older vehicles coupled with poor vehicle maintenance, inadequate road infrastructure and low fuel quality [33].

Dhaka's growth has increased over the last several decades. Due to the unplanned urbanization, air pollutant parameters have been escalated in these areas. Similarly, research was conducted on 20 urban hot spots in 20 European cities and it was found that air pollutants have exceeded the urban background concentrations due to an increase in traffic volume [34]. Also, motorized road transport in UK has been categorized as one of the largest single pollution sources in $92 \%$ of declared air quality management areas (AQMAs) which accounts for 33\% emissions of NOx and 21\% of PM10 [35]. Similarly, NOx and PM10 both are significantly increasing in Dhaka city area as well as in North American megacities like, Los Angeles, New York, and Mexico City (TABLE 4) [36,37]. In New South Wales (NSW) Australia, road transport is the single largest source of NOx emissions that contributes more than $71 \%$ of total emissions [37].

In the Asian subcontinent, some developed countries, for instance, Singapore, Japan and Hong Kong, are facing street-level air pollution problems due to an increase in the number of motorized transport [38]. In developing countries, mega cities are facing acute problems due to an increase in the ambient $\mathrm{PM}$ and $\mathrm{NO}_{2}$ concentrations as a result of rapid urbanization. In Shanghai, New Delhi, Mumbai, Guangzhou, Chongqing, Calcutta, Beijing, and Bangkok the ambient PM and $\mathrm{NO}_{2}$ concentrations frequently violate WHO guidelines [39]. Chan and Yao [40] have reported that ambient concentrations of PM10 and $\mathrm{SO}_{2}$ in the Chinese cities of Shanghai and Pearl River Delta are four to six times higher than concentrations observed in any of the cities in developed countries. One of the studies carried out recently has found that the annual average PM10 concentrations in Asian cities are four times higher than WHO guidelines [41]. Air pollutants have been significantly increased at different locations in Dhaka also in comparison with other cities throughout the world.

Air pollutants are a major environmental health problem. The studied air pollutants such as, $\mathrm{VOC}, \mathrm{CO}_{2}, \mathrm{CO}, \mathrm{SO}_{2}$, NOx, $\mathrm{H}_{2} \mathrm{~S}$, SPM, PM10, PM 2.5, and $\mathrm{Pb}$ are responsible for the development of various health hazards in communities (TABLES 5 and 6). Yelda and Mustafa [42] report that sulfur dioxide $\left(\mathrm{SO}_{2}\right)$, particle substances (PM), and nitrogen oxides (NOx) in the air can create negative effects on the environment and human health. This air pollution is the result of human activities. This pollution damages the natural processes in the atmosphere, and negatively affects public health. Currently, several cities in Africa are recognized as having unsustainable levels of pollutants negatively affecting their air quality [42]. It was found that until the 1980s, 1.3 billion people lived in cities where pollution was above the air quality standards [42]. According to the WHO, about $98 \%$ of cities in low- and middle income countries with more than 100000 inhabitants do not meet standard air quality parameters [43]. Dhaka is also included in cities whose pollution has a negative effect on the residents. However, this percentage decreases to $56 \%$ in high income countries.

Air pollutants, such as carbon monoxide $(\mathrm{CO})$, sulfur dioxide $\left(\mathrm{SO}_{2}\right)$, nitrogen oxides $(\mathrm{NOx})$, volatile organic compounds (VOCs), ozone $\left(\mathrm{O}_{3}\right)$, heavy metals, and particulate matter (PM2.5 and PM10), differ in their chemical composition, reaction properties, emission, time of disintegration and ability to diffuse in long or short distances. These air 
www.tsijournals.com | April-2018

pollutants have both acute and chronic effects on human health, affecting a number of different systems and organs. It ranges from minor upper respiratory irritation to chronic respiratory and heart disease, lung cancer, acute respiratory infections in children and chronic bronchitis in adults, aggravating pre-existing heart and lung disease, or asthmatic attacks [43]. In addition, short- and long-term exposures have also been linked with premature mortality and reduced life expectancy [44]. A similar result was also found from this study in Dhaka through the discussion with a health physician and public perception (TABLES 5 and 6).

Urban people are usually exposed to the particulates in air through their regular activities. In general human activities also largely cause an increase in air pollutants in urban areas. In this situation, people exposed to toxic air pollutants at sufficient concentrations and durations may have an increased chance of getting cancer or experiencing other serious health effects. These health effects can include damage to the immune system, as well as neurological, reproductive (e.g., reduced fertility), developmental, respiratory and other health problems [45]. Not only human, some toxic air pollutants such as lead $(\mathrm{Pb})$ can deposit onto soils or surface waters, where they are taken up by plants and ingested by animals and are eventually magnified up through the food chain. Like humans, animals may experience health problems if exposed to sufficient quantities of air toxins over time [45]. Similarly, air pollution levels are unlikely to have serious short term effects [46]. However, elevated levels and/or long term exposure to air pollution can lead to more serious symptoms and conditions affecting human health. This mainly affects the respiratory and inflammatory systems, but can also lead to more serious conditions such as heart disease and cancer. People with lung or heart conditions may be more susceptible to the effects of air pollution. In the city of Dhaka people have been suffering from various health diseases due to the significant effect of air pollution as well (TABLES 5 and 6). It is concluded that urban people should show concern regarding air pollution and its effects on health including maintaining a sustainable environment.

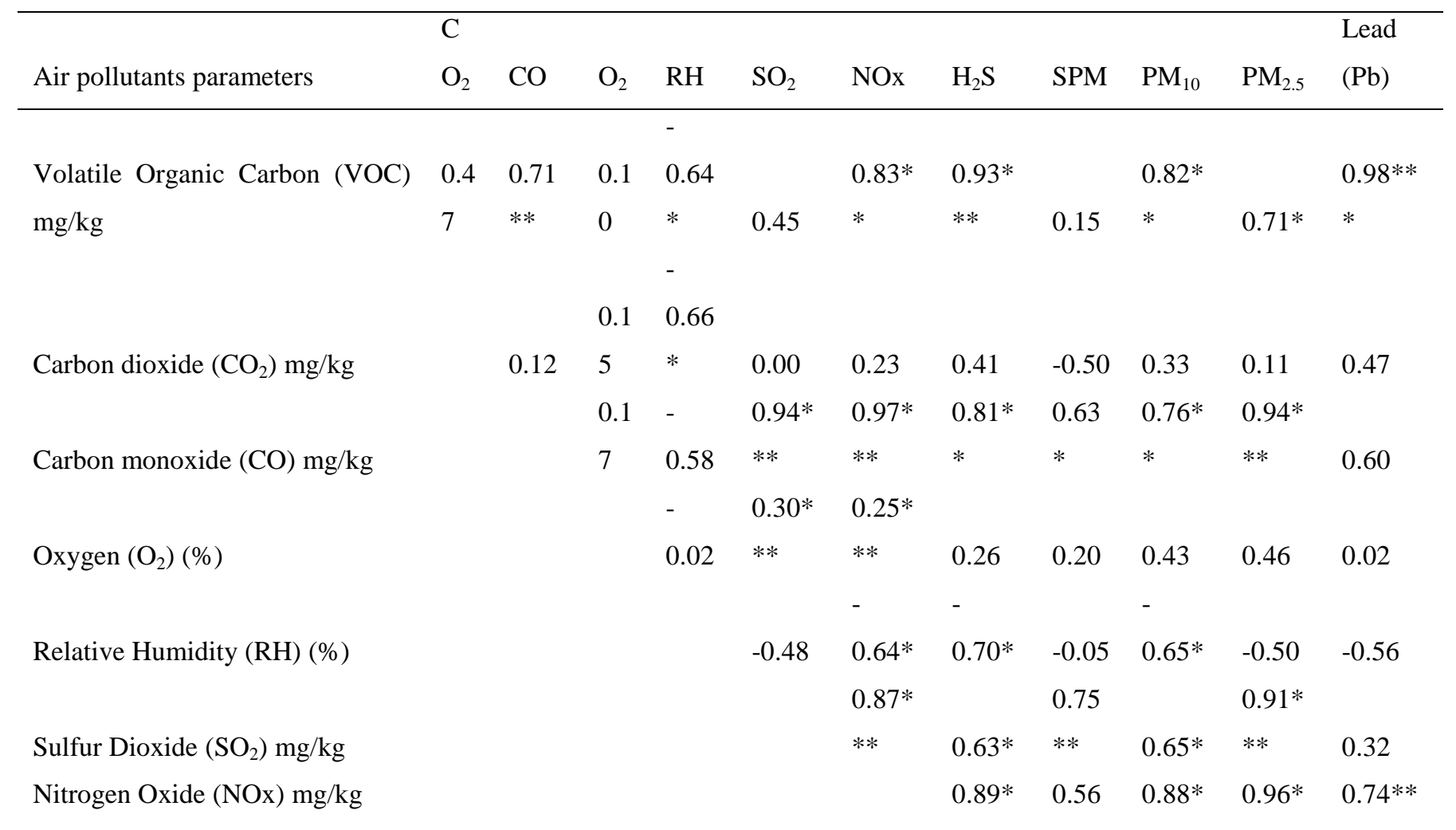


www.tsijournals.com | April-2018

Hydrogen Sulfide $\left(\mathrm{H}_{2} \mathrm{~S}\right) \mathrm{mg} / \mathrm{kg}$

$0.81 * 0.84 * 0.84 * *$

Suspended Particulate Matter

0.39

* * * *

(SPM) $\mathrm{mg} / \mathrm{kg}$

$0.33 \quad 0.69 * 0.02$

$0.85 *$

Particulate Matter $\left(\mathrm{PM}_{10}\right) \mathrm{mg} / \mathrm{kg}$

** $\quad 0.78 * *$

Particulate Matter $\left(\mathrm{PM}_{2.5}\right) \mathrm{mg} / \mathrm{kg}$

0.59

$* * *$ indicate significant difference at $1 \%(\mathrm{p}<0.01)$ level of significance, $* *$ indicate significant difference at $5 \%(0.01<\mathrm{p} \leq$ $0.05)$ level of significance, *Indicate significant difference at $10 \%(0.05<\mathrm{p} \leq 0.1)$ level of significance and others indicate insignificant difference.

TABLE 1. Correlation coefficient with significance level between air pollutant parameters at different locations in the city of Dhaka (August, 2016)

$\begin{array}{lllllllllllll}\text { Air pollutants parameters } & \mathrm{CO}_{2} & \mathrm{CO} & \mathrm{O}_{2} & \mathrm{RH} & \mathrm{SO}_{2} & \mathrm{NOx} & \mathrm{H}_{2} \mathrm{~S} & \mathrm{SPM} & \mathrm{PM}_{10} & \mathrm{PM}_{2.5} & \mathrm{Lead}^{2}\end{array}$

Volatile Organic Carbon

(VOC) $\mathrm{mg} / \mathrm{kg}$

$0.89 * *$

$0.2 \quad 0.4$

$0.75 *$

$0.85 *$

$0.85^{*}$

$0.86^{*}$

$0.71 * 0.97 * *$

$\begin{array}{lllll}* & 0.57 & 8 & 8 & 0.40\end{array}$

Carbon dioxide $\left(\mathrm{CO}_{2}\right) \mathrm{mg} / \mathrm{kg}$

$\begin{array}{llllllllll}0.86 * & 0.1 & 0.4 & 0.71 * & 0.93 * & 0.92 * & 0.94 * & 0.94 * & 0.81 * & 0.83 * * \\ * * & 4 & 0 & * & * * & * * & * * & * * & * & *\end{array}$

Carbon monoxide (CO) mg/kg

$\begin{array}{llllllll}0.1 & 0.3 & 0.96 * & 0.96 * & 0.84 * & 0.88 * & 0.87 * & 0.86 * \\ 8 & 7 & * * & * * & * * & * * & * * & * *\end{array}$

Oxygen $\left(\mathrm{O}_{2}\right)(\%)$

$$
0.5
$$

$\begin{array}{llllllll}4 & 0.29 & 0.32 & 0.41 & 0.39 & 0.39 & 0.46 & 0.19\end{array}$

Relative Humidity (RH) (\%)

$$
\begin{array}{rlllllll} 
& \multicolumn{3}{c}{0.71 *} & & \multicolumn{3}{c}{0.78 *} \\
-0.48 & -0.52 & * & 0.62 * & -0.61 & * & -0.30 \\
& & & & & & \\
& 0.90 * & 0.79 * & 0.81 * & 0.80 * & 0.87 * & 0.26
\end{array}
$$

Sulfur Dioxide $\left(\mathrm{SO}_{2}\right) \mathrm{mg} / \mathrm{kg}$ 
www.tsijournals.com | April-2018

Nitrogen Oxide (NOx) $\mathrm{mg} / \mathrm{kg}$

$0.95 * 0.97 * 0.97 * 0.94 *$

Hydrogen Sulfide $\left(\mathrm{H}_{2} \mathrm{~S}\right)$

$\begin{array}{lllll}* * & * * & * & * & *\end{array}$

$\mathrm{mg} / \mathrm{kg}$

$0.99 * 0.99 * 0.97 *$

Suspended Particulate Matter

$\begin{array}{llll}* * & * * & * * & 0.73 * *\end{array}$

$1.00 * 0.95 *$

(SPM) $\mathrm{mg} / \mathrm{kg}$

$* * \quad * * \quad 0.74 * *$

Particulate Matter $\left(\mathrm{PM}_{10}\right)$

$0.95 *$

$\mathrm{mg} / \mathrm{kg}$

$* * \quad 0.77 * *$

Particulate Matter $\left(\mathrm{PM}_{2.5}\right)$

$\mathrm{mg} / \mathrm{kg}$

0.56

$* * *$ indicate significant difference at $1 \%(\mathrm{p}<0.01)$ level of significance, $* *$ indicate significant difference at $5 \%(0.01<\mathrm{p} \leq$ $0.05)$ level of significance, *Indicate significant difference at $10 \%(0.05<\mathrm{p} \leq 0.1))$ level of significance and others indicate insignificant difference.

TABLE 2. Correlation coefficient with significance level between air pollutant parameters at different locations in the city of Dhaka (December, 2016)

\begin{tabular}{|c|c|c|c|c|c|c|c|c|c|c|c|}
\hline $\begin{array}{l}\text { Air pollutants } \\
\text { parameters }\end{array}$ & $\mathrm{CO}_{2}$ & $\mathrm{CO}$ & $\mathrm{O}_{2}$ & RH & $\mathrm{SO}_{2}$ & NOx & $\mathrm{H}_{2} \mathrm{~S}$ & SPM & $\begin{array}{l}\mathrm{PM}_{1} \\
0\end{array}$ & $\mathrm{PM}_{2.5}$ & $\begin{array}{l}\text { Lead } \\
(\mathrm{Pb})\end{array}$ \\
\hline Volatile Organic & $0.86^{* *}$ & & - & & & & & & - & & \\
\hline Carbon (VOC) $\mathrm{mg} / \mathrm{kg}$ & $*$ & 0.50 & 0.29 & -0.46 & 0.40 & 0.49 & $0.66^{*}$ & 0.62 & 0.08 & $0.69 *$ & $0.75^{* *}$ \\
\hline Carbon dioxide $\left(\mathrm{CO}_{2}\right)$ & & & - & - & & & & & & & \\
\hline $\mathrm{mg} / \mathrm{kg}$ & & 0.49 & 0.43 & $0.78 * *$ & 0.32 & 0.54 & 0.55 & $0.63 *$ & 0.17 & $0.70^{*}$ & $0.74 * *$ \\
\hline Carbon monoxide (CO) & & & - & & $0.96 * *$ & 0.70 & & & - & $0.93 * *$ & \\
\hline $\mathrm{mg} / \mathrm{kg}$ & & & 0.41 & -0.47 & $*$ & $*$ & $0.95 * *$ & 0.03 & 0.12 & $*$ & 0.25 \\
\hline Oxygen $\left(\mathrm{O}_{2}\right)(\%)$ & & & & 0.16 & -0.31 & -0.36 & -0.25 & -0.37 & 0.17 & -0.38 & -0.32 \\
\hline Relative Humidity & & & & & & & & & - & & \\
\hline$(\mathrm{RH})(\%)$ & & & & & -0.31 & -0.57 & -0.47 & -0.26 & 0.28 & $-0.65^{*}$ & -0.29 \\
\hline Sulfur Dioxide $\left(\mathrm{SO}_{2}\right)$ & & & & & & & $0.93 * *$ & & - & $0.86 * *$ & \\
\hline mg/Kg & & & & & & 0.56 & $*$ & -0.16 & 0.32 & $*$ & 0.07 \\
\hline $\begin{array}{l}\text { Nitrogen Oxide (NOx) } \\
\mathrm{mg} / \mathrm{kg}\end{array}$ & & & & & & & $0.71 * *$ & 0.49 & 0.25 & $0.81 * *$ & 0.28 \\
\hline Hydrogen Sulfide & & & & & & & & & - & $0.96 * *$ & \\
\hline$\left(\mathrm{H}_{2} \mathrm{~S}\right) \mathrm{mg} / \mathrm{kg}$ & & & & & & & & 0.11 & 0.19 & $*$ & 0.28 \\
\hline $\begin{array}{l}\text { Suspended Particulate } \\
\text { Matter (SPM) mg/kg }\end{array}$ & & & & & & & & & 0.48 & 0.28 & $0.62 *$ \\
\hline $\begin{array}{l}\text { Particulate Matter } \\
\left(\mathrm{PM}_{10}\right) \mathrm{mg} / \mathrm{kg}\end{array}$ & & & & & & & & & & -0.04 & 0.25 \\
\hline
\end{tabular}


$* * *$ indicate significant difference at $1 \%(\mathrm{p}<0.01)$ level of significance, $* *$ indicate significant difference at $5 \%$ $(0.01<\mathrm{p} \leq 0.05)$ level of significance, $*$ Indicate significant difference at $10 \%(0.05<\mathrm{p} \leq 0.1)$ level of significance and others indicate insignificant difference.

TABLE 3. Correlation coefficient with significance level between air pollutant parameters at different locations in the city of Dhaka (April, 2017)

\begin{tabular}{|c|c|c|c|c|c|c|c|c|}
\hline $\begin{array}{c}\text { Air } \\
\text { pollutants }\end{array}$ & \multicolumn{8}{|c|}{ Estimated Coefficient trend at different locations } \\
\hline $\begin{array}{l}\text { Volatile } \\
\text { Organic } \\
\text { Carbon } \\
\text { (VOC) } \\
\mathrm{mg} / \mathrm{kg}\end{array}$ & $\begin{array}{c}2.547 * * * \\
(0.0017) \\
(0.974)\end{array}$ & $\begin{array}{c}1.571 * * \\
(0.03166) \\
(0.8291)\end{array}$ & $\begin{array}{c}0.595 * * * \\
(0.0023) \\
(0.9687)\end{array}$ & $\begin{array}{l}1.075 * * * \\
(0.0042) \\
(0.9541)\end{array}$ & $\begin{array}{c}0.846 * * \\
(0.0424) \\
(0.793)\end{array}$ & $\begin{array}{c}1.834 * * \\
(0.0367) \\
(0.811)\end{array}$ & $\begin{array}{l}1.587 * * \\
(0.040) \\
(0.801)\end{array}$ & $\begin{array}{l}0.819 * * \\
(0.0420) \\
(0.7953)\end{array}$ \\
\hline $\begin{array}{l}\text { Carbon } \\
\text { dioxide } \\
\left(\mathrm{CO}_{2}\right) \\
\mathrm{mg} / \mathrm{kg}\end{array}$ & $\begin{array}{l}0.070 * \\
(0.134) \\
(0.580)\end{array}$ & $\begin{array}{c}0.115 * * \\
(0.0466) \\
(0.78125)\end{array}$ & $\begin{array}{l}0.088 * * \\
(0.0217) \\
(0.8659)\end{array}$ & $\begin{array}{c}0.123 \\
(0.302) \\
(0.339)\end{array}$ & $\begin{array}{c}0.024 \\
(0.8596) \\
(0.0122)\end{array}$ & $\begin{array}{c}0.060 \\
(0.00004) \\
(0.9976)\end{array}$ & $\begin{array}{c}0.181 \\
-\end{array}$ & $\begin{array}{l}0.520 * * \\
(0.046) \\
(0.781)\end{array}$ \\
\hline $\begin{array}{l}\text { Oxygen } \\
\left(\mathrm{O}_{2}\right)(\%)\end{array}$ & $\begin{array}{c}0.825 \\
(0.320) \\
(0.3200)\end{array}$ & $\begin{array}{c}0.134 \\
(0.854) \\
(0.0131)\end{array}$ & $\begin{array}{c}3.094 * * \\
(0.0466) \\
(0.78125)\end{array}$ & $\begin{array}{c}0.392 * \\
(0.0605) \\
(0.7422)\end{array}$ & $\begin{array}{c}0.455 \\
(0.1456) \\
(0.560)\end{array}$ & $\begin{array}{l}1.093 * * * \\
(0.0018) \\
(0.9730)\end{array}$ & $\begin{array}{c}0.869 \\
(0.000000005) \\
(0.9999)\end{array}$ & $\begin{array}{c}0.442 \\
(0.14278) \\
(0.565)\end{array}$ \\
\hline $\begin{array}{l}\text { Relative } \\
\text { Humidity } \\
(\%)\end{array}$ & $\begin{array}{c}0.165 \\
(0.6392) \\
(0.0825)\end{array}$ & $\begin{array}{c}-0.082 \\
(0.4686) \\
(0.185)\end{array}$ & -0.0000 & -0.0000 & $\begin{array}{c}0.125 \\
(0.2240) \\
(0.4375)\end{array}$ & $\begin{array}{l}-0.095 * \\
(0.0625) \\
(0.7369)\end{array}$ & $\begin{array}{c}0.125 * \\
(0.0823) \\
(0.6879)\end{array}$ & $\begin{array}{c}0.197 * * * \\
(0.0004) \\
(0.9889)\end{array}$ \\
\hline $\begin{array}{l}\text { Sulfur } \\
\text { Dioxide } \\
\left(\mathrm{SO}_{2}\right) \\
\mathrm{mg} / \mathrm{kg} \\
\text { Nitrogen } \\
\text { Oxide } \\
(\mathrm{NOx}) \\
\mathrm{mg} / \mathrm{kg}\end{array}$ & $\begin{array}{l}0.880 * * \\
(0.0119) \\
(0.9089)\end{array}$ & $\begin{array}{c}4.616 * \\
(0.0546) \\
(0.7582)\end{array}$ & $\begin{array}{c}1.352 * * * \\
(0.0008) \\
(0.9836) \\
2.770 * * \\
(0.0508) \\
(0.7689)\end{array}$ & $\begin{array}{c}1.918 * * \\
(0.0466) \\
(0.78125)\end{array}$ & $\begin{array}{c}2.920 * * \\
(0.0466) \\
(0.78125)\end{array}$ & $\begin{array}{c}1.698 * * \\
(0.0466) \\
(0.78125)\end{array}$ & $\begin{array}{c}1.671 * * \\
(0.0466) \\
(0.78125)\end{array}$ & $\begin{array}{c}1.494 * \\
(0.0615) \\
(0.739) \\
\\
2.561 * * \\
(0.0466) \\
(0.78125)\end{array}$ \\
\hline $\begin{array}{l}\text { Hydrogen } \\
\text { Sulfide } \\
\left(\mathrm{H}_{2} \mathrm{~S}\right) \\
\mathrm{mg} / \mathrm{kg}\end{array}$ & $\begin{array}{c}0.435 * * * \\
(0.0003) \\
(0.9917)\end{array}$ & $\begin{array}{c}-2.350 \\
(0.5512) \\
(0.1298)\end{array}$ & $\begin{array}{l}1.521 * * \\
(0.0273) \\
(0.8445)\end{array}$ & $\begin{array}{c}0.547 \\
(0.7802) \\
(0.0301)\end{array}$ & $\begin{array}{l}1.823 * * \\
(0.0427) \\
(0.7930)\end{array}$ & $\begin{array}{c}1.806 \\
(0.123) \\
(0.600)\end{array}$ & $\begin{array}{c}1.339 \\
(0.153) \\
(0.5458)\end{array}$ & $\begin{array}{c}0.652 * \\
(0.0606) \\
(0.7420)\end{array}$ \\
\hline $\begin{array}{l}\text { Suspended } \\
\text { Particulate } \\
\text { Matter } \\
(\mathrm{SPM}) \\
\mathrm{mg} / \mathrm{kg}\end{array}$ & $\begin{array}{c}6.755 * * * \\
(0.0119) \\
(0.9089)\end{array}$ & $\begin{array}{l}4.853 * * \\
(0.0546) \\
(0.7582)\end{array}$ & $\begin{array}{l}1.236 * * \\
(0.0008) \\
(0.9836)\end{array}$ & $\begin{array}{l}2.087 * * \\
(0.0502) \\
(0.7708)\end{array}$ & $\begin{array}{c}1.971 * * \\
-\end{array}$ & $\begin{array}{c}1.416 * * \\
-\end{array}$ & $\begin{array}{c}1.769 * * \\
(0.01372) \\
(0.9005)\end{array}$ & $\begin{array}{l}1.677 * * \\
(0.0615) \\
(0.7396)\end{array}$ \\
\hline $\begin{array}{l}\text { Particulate } \\
\text { Matter }\end{array}$ & $\begin{array}{l}2.106 * * \\
(0.0330)\end{array}$ & $\begin{array}{l}3.799 * * \\
(0.0466)\end{array}$ & $\begin{array}{l}2.016 * * \\
(0.0335)\end{array}$ & $\begin{array}{l}1.383 * * \\
(0.0408)\end{array}$ & $\begin{array}{l}1.191 * * \\
(0.0466)\end{array}$ & $\begin{array}{l}1.097 * * \\
(0.0427)\end{array}$ & $\begin{array}{l}1.815 * * \\
(0.0466)\end{array}$ & $\begin{array}{l}1.803 * * \\
(0.0415)\end{array}$ \\
\hline
\end{tabular}


www.tsijournals.com | April-2018

$\begin{array}{lcccccccc}\begin{array}{l}\left(\mathrm{PM}_{10}\right) \\ \mathrm{mg} / \mathrm{kg}\end{array} & (0.8243) & (0.7812) & (0.8226) & (0.7989) & (0.7812) & (0.7930) & (0.7812) & (0.7966) \\ & & & & & & & & \\ \text { Particulate } & 1.395 * * & 59.41 * * & 1.212 * * & 3.703 * * & 14.74 * * & 3.262 * * & 9.704 * * \\ \text { Matter }(\mathrm{PM} & (0.0466) & (0.0466) & (0.0466) & (0.0466) & (0.0466) & (0.0466) & (0.0466) & (0.0466) \\ 2.5) \mathrm{mg} / \mathrm{kg} & (0.7812) & (0.7812) & (0.7812) & (0.7912) & (0.7812) & (0.7812) & (0.7812) & (0.7812) \\ & & & & & & & & \\ \mathrm{Lead}(\mathrm{Pb}) & 637.755^{* *} & 3472.22 * * & 15.625 * * & \mathrm{NA} & 9.060^{* *} & 40.11^{* *} & 32.249 * * & 136.46 * * \\ \mathrm{mg} / \mathrm{kg} & (0.0466) & (0.0466) & (0.0466) & - & (0.0466) & (0.0466) & (0.0466) & (0.0466) \\ & (0.781) & (0.781) & (0.781) & & (0.781) & (0.781) & (0.781) & (0.781)\end{array}$

$* * *$ indicate significant difference at $1 \%(\mathrm{p}<0.01)$ level of significance, $* *$ indicate significant difference at $5 \%(0.01<\mathrm{p} \leq$ $0.05)$ level of significance, ${ }^{*}$ Indicate significant difference at $10 \%(0.05<\mathrm{p} \leq 0.1)$ level of significance and others indicate insignificant difference. In addition, ( ) value indicate $\operatorname{Pr}(>\mathrm{F})$ and [ ] indicate R-Square.

TABLE 4. Coefficient trend of air pollutant parameters at different locations in the city of Dhaka (July 2016- June, 2017)

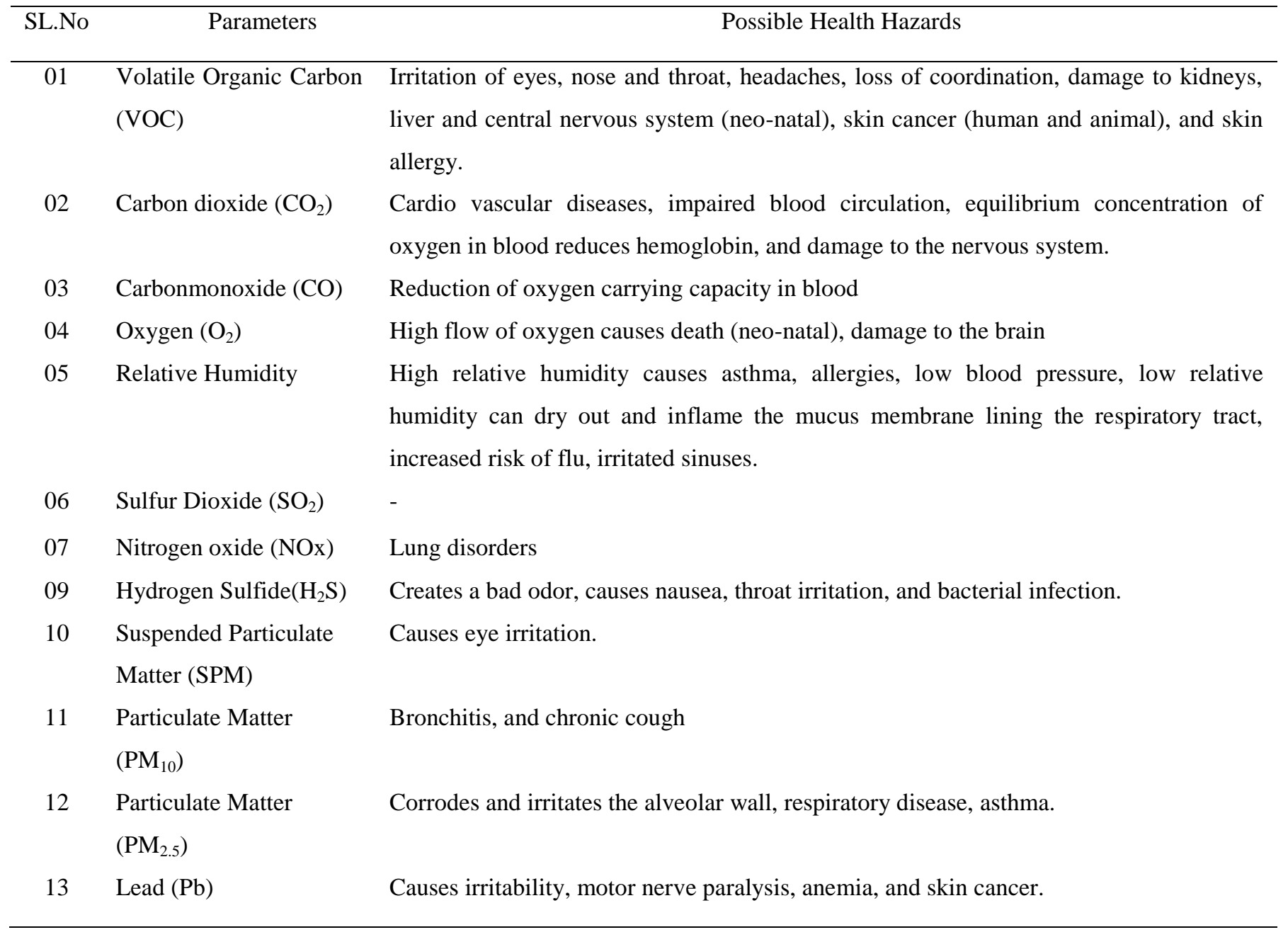

TABLE 5. Public perception regarding possible health effects of air pollutants at different locations in the city of

Dhaka 


\begin{tabular}{|c|c|c|}
\hline Sl.No & Parameters & Possible Health Hazards \\
\hline 01 & $\begin{array}{l}\text { Volatile Organic } \\
\text { Carbon (VOC) }\end{array}$ & $\begin{array}{l}\text { Eye, nose and throat irritation, headaches, damage to kidneys, liver cancer (human and } \\
\text { animal). }\end{array}$ \\
\hline 02 & Carbon dioxide $\left(\mathrm{CO}_{2}\right)$ & Dizziness, decrease consciousness \\
\hline 03 & Carbonmonoxide $(\mathrm{CO})$ & Reduction of oxygen carrying capacity in blood, and finally death (in severe case) \\
\hline 04 & Oxygen $\left(\mathrm{O}_{2}\right)$ & High flow of oxygen causes lung injury, trauma, and vision impairment to infant. \\
\hline 05 & $\begin{array}{l}\text { Relative Humidity } \\
\text { (RH) }\end{array}$ & $\begin{array}{l}\text { Increased risk of flu, viral infection, and high relative humidity causes asthma, allergies, } \\
\text { respiratory tract infection, low relative humidity can dry out throat and inflame the mucus } \\
\text { membrane lining the respiratory tract, and throat and itchy eyes. }\end{array}$ \\
\hline 06 & Sulfur Dioxide $\left(\mathrm{SO}_{2}\right)$ & Damages of chest constriction, headache, vomiting and death due to respiratory disease. \\
\hline 07 & Nitrogen oxide (NOx) & Inhibit cilia action so that soot and dust penetrate far into the lungs, headaches. \\
\hline 09 & $\begin{array}{l}\text { Hydrogen Sulfide } \\
\left(\mathrm{H}_{2} \mathrm{~S}\right)\end{array}$ & Creates a bad odor, causes nausea, eye and throat irritation. \\
\hline 10 & $\begin{array}{l}\text { Suspended Particulate } \\
\text { Matter (SPM) }\end{array}$ & Causes allergy, rhinitis, asthma, droplet infection of teeth. \\
\hline 11 & $\begin{array}{l}\text { Particulate Matter } \\
\left(\mathrm{PM}_{10}\right)\end{array}$ & Causes allergic rhinitis, chronic cough, chronic phlegm, breathlessness. \\
\hline 12 & $\begin{array}{l}\text { Particulate Matter (PM } \\
\text { 2.5) }\end{array}$ & Corrodes and irritates the alveolar wall, impairs lung function, silicosis. \\
\hline 13 & Lead $(\mathrm{Pb})$ & $\begin{array}{l}\text { Causes irritability, motor nerve paralysis, anemia, miscarriage, cancer, blue line on gum, } \\
\text { osteoporosis, and decreased level of consciousness. }\end{array}$ \\
\hline
\end{tabular}

TABLE 6. Health physician's perception regarding possible health effects of air pollutants at different locations in the city of Dhaka.

\section{Causes of air pollution in Dhaka city}

Air pollution is the introduction of harmful substances in the air that have detrimental impacts to the environment and humanity. It occurs when harmful substances such as foreign gases, odor, dust, or fumes are present in the air that can be harmful to human beings. Several causes have been identified for air pollution in Dhaka.

\section{Population density}

Dhaka is one of the most densely populated cities in the world, with an estimated population of more than 8 million. Air pollution has emerged as an acute problem in the city of Dhaka. There is a significant relationship between population and pollution in different regions. For example, a European city of 1 million people is exposed to six times higher nitrogen dioxide pollution than a city of 1 million people in India [47]. Different regions showed a wide range of nitrogen dioxide 
www.tsijournals.com | April-2018

surface concentrations in urban areas of around 1 million people. Europe was ranked highest at over 1.3 parts per billion, while India's 1-million population cities came in at just over 0.2 parts per billion. For cities with population of 10 million people, the results were similar: 3.9 parts per billion in Europe versus 0.5 parts per billion in India. Air pollution has been a major issue in China as well as Dhaka city $[43,47]$.

\section{Unplanned industrialization and urbanization}

Unplanned urbanization and industrialization is a common scenario in the city of Dhaka. This city is expanding towards the periphery without consideration of environmental degradation. This is one of the major causes of increasing pollution levels of the air in Dhaka. With the current rate of industrialization and increased manufacturing activities in Dhaka city, high levels of smoke, sulfur dioxide, particulate matter, organic compounds, and carbon monoxide are released into the air. The air has become increasingly unhealthy in Dhaka. Higher amounts of harmful particles have been found in the air of the city of Dhaka. Bangladesh is the fourth, among 91 countries with the worst urban air quality in its recent air pollution monitoring report [43]. Almost 90 percent of the people living in these cities were being exposed to dangerous levels of air pollution. Unplanned industrialization and urbanization can be identified as factors that are responsible for increases in air pollutants in Dhaka [48].

\section{Traffic pressure}

A high number of motorized vehicles are clogging up roads and contributing further to poor air quality. Besides the large number of cars, the ever-present conflict between motorized and non-motorized transport such as rickshaws means urban traffic is often brought to a standstill for long periods of time resulting in not only health and environmental damage but huge economic losses due to lost time [29]. These groups of people have been suffering in an unhealthy environment due to traffic pressure in Dhaka. The daily total emissions of NOx, HC, CO, PM, and SOx are estimated using the daily fuel consumption and total traffic flows in Dhaka. Estimated daily emissions are 42, 39, 314, 14, and 42 t for NOx, HC, CO, PM, and SOx, respectively [49].

\section{Brick fields}

In Bangladesh, the brick kiln industry is one of the fastest-growing sectors, supporting the booming infrastructure and construction industry, with current manufacturing capacity of 12 billion bricks a year from 4,500 brick kilns surrounding all major cities of Dhaka, Khulna, Rajshahi, and Chittagong, and expected to grow $50 \%$ by 2020 [50,51].The total emissions are estimated at 23,300 $\mathrm{t}$ of $\mathrm{PM}_{2.5}, 15500 \mathrm{t}$ of sulfur dioxide $\left(\mathrm{SO}_{2}\right)$, 302,000 $\mathrm{t}$ of carbon monoxide (CO), $6000 \mathrm{t}$ of black carbon, and 1.8 million $\mathrm{t}$ of $\mathrm{CO}_{2}$ from these clusters, to produce 3.5 billion bricks per year, using a fixed chimney bull trench kiln technology that is not energy efficient and predominantly using coal and agricultural waste as fuel. The associated health impacts largely fall on the densely populated districts of Dhaka Metropolitan Area (DMA) [52]. 
www.tsijournals.com | April-2018

\section{Climate changes}

Atmospheric warming associated with climate change has the potential to increase ground-level ozone in many regions, which may present challenges for compliance with the ozone standards in the future. Emissions of pollutants into the air can result in changes to the climate. Ozone in the atmosphere warms the climate, while different components of particulate matter (PM) can have either warming or cooling effects on the climate. For example, black carbon, a particulate pollutant from combustion, contributes to the warming of the Earth, while particulate sulfates cool the earth's atmosphere [53]. Due to the changes of climatic parameters, air quality in Dhaka has been changing for many decades [54].

\section{Conclusion}

Air pollutants are increasing in the Mega city of Dhaka in Bangladesh. This is an awful threat for the sustainable living of human beings in this city. People have been facing various diseases due to the increase of toxic air pollutants. Air pollutants such as, volatile organic carbon(VOC), carbon dioxide $\left(\mathrm{CO}_{2}\right)$, carbon monoxide $(\mathrm{CO})$, oxygen $\left(\mathrm{O}_{2}\right)$, sulfur dioxide $\left(\mathrm{SO}_{2}\right)$, nitrogen oxide (NOx), hydrogen sulfide $\left(\mathrm{H}_{2} \mathrm{~S}\right)$, suspended particulate matter $(\mathrm{SPM})$, particulate matter $\left(\mathrm{PM}_{10}\right)$, and particulate matter $\left(\mathrm{PM}_{2.5}\right)$ have increased significantly in Dhaka. Due to the increasing levels that exceed the standard limits of each pollutant, different health concerns have developed among the community people in this city. In this manner, rate of mortality has been increasing also. As a result, research on air quality parameters and their impacts on human health are absolutely important. It is expected that the monitoring of air quality parameters regularly and discovering their impacts on a sustainable environment will provide standard guidelines for the improvement of urbanization in relation to the sustainable livelihood.

\section{Acknowledgement}

Authors would like to thank to the Laboratory of Environmental Science at BSMRAU and Biological Research Division at Soil and Environment Section of BCSIR. Finally, we are especially thankful to BSMRAU for their valuable funding.

\section{References}

1. Daly A, Zannetti P. An Introduction to Air Pollution - Definitions, Classifications, and History. The Arab School for Science and Technology (ASST) and The Enviro Comp Institute 2007.

2. Clean Air Act. Summary of the Clean Air Act 1970.

3. Steven P. Representations and decision rules in the theory of self-deception. Behavioural and Brain Sciences. $2011 ; 34: 35-7$.

4. Álvaro GL, Antonio LG, Rafael PM, et al. Finite mixture models to characterize and refine air quality monitoring networks. Science of the Total Environment. 2014;485-6, 292-9.

5. Sicard P, Lesne O, Alexandre N, et al. Air quality trends and potential health effects e Development of an aggregate risk index. Atmospheric Environment. 2011;45:1145-53. 
www.tsijournals.com | April-2018

6. Felix JR, Anne LD. Air pollution and very low birth weight infants: A target Population. Pediatrics. 2006;118:15664.

7. Arden CP, Richard TB, Micheal JT. Lung cancer, cardiopulmonary mortality and long-term exposure to fine particulate air pollution. JAMA. 2002;287:1132-41.

8. Ajayi AB, Dosunmu OO. Environmental hazards of importing used vehicles into Nigeria. Proceedings of International Symposium on Environmental Pollution Control and Waste Management. 2002;521-32.

9. Abam FI, Unachukwu GO. Vehicular emission and air quality standards in Nigeria. European Journal of Scientific Research. 2009;34:550-60.

10. Olajire, Azeez L, Oluyemi EA. Exposure to hazardous air pollutants along Oba Akran road, Lagos - Nigeria. Chemosphere. 2011;84:1044-51.

11. Lirong Z, Xinming W, Quisheng H, et al. Exposure to hazardous volatile organic compounds, PM10 and CO while walking along streets in urban Guangzhou, China. Atmospheric Environment. 2004;38:6177-84.

12. Hopkins JR, Evans MJ, Lee JD, et al. Direct estimates of emission from the Megacity of Lagos. Atmospheric Chemistry and Physics. 2009;9:8471-77.

13. Olukayode T. The case of Lagos: Air quality improvement project, Lagos Metropolitan Area Transport Authority. $2005 ; 1-22$.

14. Mathuros R, Daam S, Panida N, et al. Assessment of Potential cancer risk in children exposed to urban air pollution in Bangkok. Elsevier 2006;1-10.

15. Enemeri JJ. Vehicular emission, environmental and health implications. Conference on Phase-out of Leaded Gasoline in Nigeria. 2001;1-6.

16. Dotun O. Air quality management. Air Quality Management Resource Centre, Bristol. 2007;1-33.

17. Seinfeld JH. Air pollution: a half century of progress. AIChE Journal. 2004; 50:1096-108.

18. Atkinson R. Atmospheric chemistry of VOCs and NOX. Atmospheric Environment. 2000;34:2063-101.

19. Khanna N. Measuring environmental quality: an index of pollution. Ecol Econ. 2000;35:191-202.

20. Murena F. Measuring air quality over large urban areas: development and application of an air pollution index at the urban area of Naples. Atmos Environ. 2004;38:6195-202.

21. Kyrkilis G, Chaloulakou A, Kassomenos PA, et al. Development of an aggregate AQI for an urban Mediterranean agglomeration: relation to potential health effects. Environ Int. 2007;33:5.

22. Cairncross EK, John J, Zunckel M. A novel air pollution index based on the relative risk of daily mortality associated with short-term exposure to common air pollutants. Atmos Environ. 2007;41:8442-54.

23. Kassomenos P, Kelessis A, Petrakakis M, et al. Air Quality assessment in a heavily-polluted urban Mediterranean environment through Air Quality indices. Ecol Indic. 2012;18:259-68.

24. Llop E, Pinho P, Matos P, et al. The use of lichen functional groups as indicators of air quality in a Mediterranean urban environment. Ecol Indic. 2012;13:215-21.

25. Plaia A, Ruggieri M. Air quality indices: a review. Rev. Environ. Sci. Bio-technol. 2011;10:165-79.

26. Sicard P, Talbot C, Lesne O, et al. The Aggregate Risk Index: An intuitive tool providing the health risks of air pollution to health care community and public. Atmospheric Environment. 2012;46:11-16.

27. Khondkar AS. Dhaka Sitting on a Sleeping Volcano, Bangladesh. 2008.

28. The World Bank. Cleaning Dhaka and Bangladesh's Air. 2014. 
www.tsijournals.com | April-2018

29. World Population Review. Dhaka Population. 2017.

30. NIOSH Manual of Analytical Methods. Fourth Edition LEAD by GFAAS: METHOD 1994;2:2-4

31. World Health Organization. 2014.

32. Cities Alliance. The Benefits of Urban Environmental Planning, a Cities Alliance Study on Good Practices and Useful Tool. 2007;162.

33. Wang H, Fu L, Zhou Y, et al. Trends in vehicular emissions in China's mega cities from 1995. Environmental Pollution. 2010; 158:394-400.

34. Moussiopoulos N, Kalognomou E A, Douros I, et al. Air pollution level at hotspot areas of selected European cities. Proceeding of 10th Conference on Harmonization within Atmospheric Dispersion Modelling for Regulatory Purposes. Sissi Crete pp. 2005;283-7.

35. Faulkner M, Russell P. Review of Local Air Quality Management, A report to DEFRA and The Devolved Administrations. 2010;98.

36. Parrish DD, Singh HB, Molina L, et al. Air quality progress in North American megacities: A review Atmospheric Environment. 2011;45:7015-25.

37. U.S. EPA (U.S. Environment Protection Agency). Our Nation's Air Status and Trends through 2010, EPA. 2012;454/R-12-001, p.32.

38. Edesess M. Roadside Air Pollution in Hong Kong: Why is It still so Bad? School of Energy and Environment, City University of Hong Kong. 2011;19.

39. Baldasano JM, Valera E, Jimenez P. Air quality data from large cities. Science of the Total Environment. 2003;307:141-65

40. Chan CK, Yao X. Air pollution in mega cities in China. Atmospheric Environment. 2008;42:1-42

41. Atash F. The deterioration of urban environments in developing countries: Mitigating the air pollution crisis in Tehran, Iran Cities. 2007;24:399-409

42. Yelda AT, Mustafa K. Air Pollutants and Its Effects on Human Healthy: The Case of the City of Trabzon, Advanced Topics in Environmental Health and Air Pollution Case Studies. 2011.

43. WHO (World Health Organization). Air pollution levels rising in many of the world's poorest cities. 2016.

44. Marilena K, Elias C. Human health effects of air pollution. Environmental Pollution. 2008;151:362-7.

45. EPA (Environmental Protection Agency). Health and Environmental Effects of Hazardous Air Pollutants. 2017.

46. Department for Environment Food and Rural Affairs. Effect of air pollution. 2017.

47. Smith B. NASA Study Finds Connection between Population and Pollution. 2013.

48. Haque AN. Environmental Pollution in Bangladesh. 2017.

49. Karim MM, Matsui H, Ohno T, et al. Current State of Traffic Pollution in Bangladesh and Metropolitan Dhaka. 2017.

50. World Bank. Small study on air quality of impacts of the North Dhaka brickfield cluster by modeling of emissions and suggestions for mitigation measures including financing models. Consultant report prepared by Bangladesh University of Engineering and Technology for the World Bank, Washington DC. 2007. 
www.tsijournals.com | April-2018

51. UNDP. Improving kiln efficiency in the brick making industry. GEF-United National Development Program, UNDP, Dhaka. 2011.

52. Sarath K, Guttikunda, Bilkis AB, et al. Particulate pollution from brick kiln clusters in the Greater Dhaka region, Bangladesh. Air Qual Atmos Health. 2012.

53. US Environmental Protection Agency (USEPA). Air Quality and Climate Change Research. 2017.

54. Bilkis AB, Philip KH, Markwitz A. Air pollution by fine particulate matter in Bangladesh. Atmospheric Pollution Research. 2013;4:75-86. 